\title{
THE "CORRESPONDENCE" OF NICOGHAYOS ADONTS
}

Dedicated to the $150^{\text {th }}$ birth anniversary of the great byzantinist and armenologist

\section{Abstract}

The letters of famous people are national and universal-sounding events. This is a reality from antic times, the manifestations of which are also present in the ancient, medieval, as well as new and modern Armenian literature.

We have in our possession 135 letters of the internationally renowned byzantinist, armenologist, philologist and historian Nicoghayos Adonts, written from 1893 to 1940.

The 135 letters of Nicoghayos Adonts, with corresponding notes, were prepared to publication by historian Petros Hovhanissian, who devoted his whole life to the study and publication of Adont's scientific heritage. The $7^{\text {th }}$ volume of the works of the famous scientist is dedicated to these letters.

Adonts' "Correspondence" contains numerous letters addressed to N. Marr, N. Akinian, G. Hovsepian, T. Gushakian, K. Zarian and others, the theses in which are basic and can still be used by linguists, critics, politicians, historians and people involved in science in general.

Keywords: N. Adonts, N. Marr, Brussels, Paris, Byzantium, Armenia, science, patriotism, Armenian Issue, genocide.

\section{Introduction}

The letters of famous people are national and universal-sounding events. This is a reality from antic times, the manifestations of which are also present in the ancient, medieval, as well as new and modern Armenian literature. It is enough to remember the letters of Movses Khorenatsi, Ghazar Parpetsi, Nerses Shnorhali, Khachatur Abovian, Gevorg Akhverdian, Hovhannes Tumanian, Avetik Isahakian and others, which are of public value and resonance.

\section{The Pedagogical value of Adonts' letters}

We have in our possession 135 letters of the internationally renowned byzantinist, armenologist, philologist and historian Nicoghayos Adonts, written from 1893 to 1940.

Adonts had an interesting life. Born in 1871 in the village of Brnakot of the province of Syunik, he learned from an early age that he was of noble descent from both his father 
and mother. The young boy was educated in the school of the Tathev Monastery, then in the Gevorkian Seminary, and then in the Russian Gymnasium of Tiflis (Georgia).

Always having a great thirst for education, thanks to the pension of the great national benefactor Alexander Mantashian, he studied in the faculties of Eastern Languages and History of St. Petersburg University, where his extraordinary capacity of learning aroused the admiration of the lecturers, especially his teacher and supervisor Nicolas Marr. Under the sponsorship of the latter, Adonts left to continue his studies in famous Europeans universities and libraries. He went to London, Paris, Vienna, Munich, Strasbourg, Venice, Brussels and other European cities. He studied with famous byzantinists and armenologists, became proficient in understanding English, French, German, ancient classical languages as Greek, Syriac, Latin and cuneiform scripts of different nations.

The 135 letters of Nicoghayos Adonts, with corresponding notes, were prepared to publication by historian Petros Hovhanissian, who devoted his whole life to the study and publication of Adont's scientific heritage. The $7^{\text {th }}$ volume of the works of the famous scientist is dedicated to these letters.

We see almost nothing in Adont's letters about his own life. Everything is connected with education (this is the first period of letters), and then with his scientific and social activities. Adonts worked at the University of Brussels for many years. Mushegh Ishkhan, who studied at that University for two years, says in his memoirs that Adonts would "take the professors of the University to the water spring and bring them back thirsty". Adonts was able to value himself and his nation in front of strangers: "He was an Armenian man in the traditional, modern, noble sense of the word.

Adonts' letters are addressed to the editors-in-chief of Armenian and foreign periodicals of the time, as well as to prominent Armenian and foreign scholars, to whom he addressed urgent scientific and national questions.

Among the letters of the first period a large number is addressed to $\mathrm{N}$. Marr and were written from different cities of Europe and are connected with the problems of education. In those letters, which were mostly in Russian, Adonts tells about his achievements in education, future goals and impressions he received from European cities. On November 18, 1900, he wrote about Paris: "The city is wonderful in its appearance and really beautiful. The squares are especially wonderful, decorated with wonderful monuments. The whole history of France can be studied, not in a bad way at all, by wandering in these parks and squares, everything you know from gymnasium. That year an international exhibition was opened in Paris, in which many nations had their pavilions. Adonts toured the exhibition, where there was no Armenian pavilion, and looked for Armenian exhibits 
in Russian and Turkish pavilions. The Turkish pavilion was miserable. Between the lines, he reports that they say $\mathrm{H}$. Gelzer was going to write an article praising Turks on the Armenian Issue. I don't know how true that is, but I am sorry that he was so misle. The Armenian Gospel of the Moscow Lazarian Seminary, written in 887, was displayed in the Russian pavilion. The coins of Tigran the Great and the Rubenids dynasty were sold in some Armenian kiosks in Paris, which he was careful to buy for fear that they were counterfeit. He watched with a special envy the very exemplary pavilions of the Balkan countries with small population.

There are many letters written in Armenian to Karapet Yezian, in which he announces that he intends to study comparative linguistics at the Sorbonne University with Antoine Meillet and the Syriac language with Auguste Carrière.

It turns out that Adonts had financial difficulties during his studies, about which he speaks very restraint. For example, he never accepted that an Armenian should look pour in foreign countries and be dressed in a no decent manner. He dressed as neatly and fashionable as possible and demanded the same from his Armenian students. The pension he received from Mantashian was sometimes not enough to buy presentable clothes and books. He applied to Karapet Yezian to intervene in Mantashian's fund to increase his pension. And finally the issue was solved when he personally met Mantashian in Paris. In the letter of March 8, 1801, to N. Marr, we read: "I am extremely happy to inform you that my incident ended extremely successfully. Here in Paris, I had the opportunity to talk to Mantashev. He received me very kindly. He asked some questions and in the end he agreed to continue the sponsorship for another year. He sent a telegram to Tiflis and I received the money the other day.

In his letters, the future famous byzantinist often speaks about his researches in Byzantine sources, constantly comparing them with the reports of Armenian historians. He very diligently compared the History of Armenia of Faust of Byzantium with the works of Amianus Marcelinos talking about the same people and his historical events.

Adonts was closely following the Armenian and foreign-language press. There are especially many letters addressed to the editorial board of "Handes Amsorea", to which he was a subscriber for many years.

In 1904, in his review "Messenger of Literature and Art", Adonts thanked G. Aristakesian, who had undertaken the obligation to provide the review financially, and informed the readers that the artistic section of the review would be edited by the famous painter Vardkes Sureniants.

Keeping in focus Western and Eastern Armenian literature, fluent in both branches 
of Armenian language, Adonts tried to undertake the noblel task of solving the problems of young and talented Armenian writers. On March 2, 1904, he wrote a letter to the Council of Armenian Churches of Petersburg to help Atom Yarjanian, a student at the Sorbonne University, who had symptoms of tuberculosis. "His future is connected with Armenian literature, his loss will be a loss for Armenian literature.

Adonts' historical and philological interests were wide. In a letter written to Galust Ter-Mkertchian on November 18, 1908, he said that he had learned from Marr that G. Ter-Mkertchian had found information about the origin of the Tsat nation in the Armenian sources. Later, in 1911, Adonts' article On the Origin of Armenian- Tsats was published in the volume I of the armenologist's works.

If there were manuscripts that the great scientist could not have at his disposal, he wrote to the specialists to send him copies of them. In Europe he was often annoyed by the lack of Armenian books and he kept asking his close friends to send him those books.

He has several letters addressed to Archimandrite Tirayr, who devoted his whole life to study Frik's work, but was able to publish only in 1952 in New York a valuable and large volume entitled Frik, Collection of Poems, in which he denied that the poet was from Cilicia, and according to the language of his poems, he considered him born in Artsakh.

There are letters addressed to Karapet Kostanian, whose greatest work was the publication in 1910 of Grigor Magistros' letters in Alexandropole. In his letter of April 28, 1917, Adonts says that the letter of August 1916 was lost, because he had gone to his native country. In the summer of 1916 he took part in archeological expeditions in the cities of Van, Mush and Karin.

The Armenian Issue and the historical rights of the Armenian people were one of the main problems of the scientist. On April 14, 1918, Adonts sent a telegram to the German ambassador in Constantinople. He wrote with legitimate anger in this telegram: "Taking advantage of the retreat of the Russian army, the Turkish troops immediately invaded the defenseless country, moreover, they murdered not only the Turkish-Armenians, but also all the Russian-Armenans. Opposing the conditions of peace, that recognized the right of the whole Caucasus to self-determination, the Turkish army moved to Kars and Ardahan, deserting the country and massacring the Christian population. At that time, Adonts was the plenipotentiary of the National Council of Petrograd and, at the same time, he worked as a professor at the University of Petrograd.

On November 7, 1920, the professor sent an angry letter to the editor of the "Times" of London. It seems that the letter is written today. He angrily recalls how the French generals set up with the Turkish bandits on the corpses of a handful of Armenians who 
took refuge in Cilicia. He criticizes the rulers of England, France and Italy, on whose conscience the Armenian Issue is like a heavy stone. Armenians have been suffering under the pressure of fraud and betrayal for half a century: "Now that the almost impossible had been done, Russian communism has fallen on their backs, this time with Turkish barbarism.

Adonts finishes his letter with the conclusion that maybe the Armenians will turn away from Europe once and forever with the dolourous conviction that the best of human virtues, the conscience, has been hopelessly silenced there. The letter was also published in the $6^{\text {th }}$ Volume of Adonts' works.

Adonts has rightly taken on the sacred role of regulator of the Armenian intellectual life. He was very concerned about the issue of educating the new Armenian generation with a patriotic spirit and national dignity.

On October 23, 1930, addressing the editorial office of "Apaga" newspaper, Adonts on behalf of the Armenian Literary Union of Paris, reminded that November 8 marked the centenaries of the birth of Mikael Nalbandian and Raphael Patkanian. He was convinced that the patriotic heritage of Nalbandan and Patkanian should be precious to the Armenian people.

It was very important for Adonts to be armed with professional knowledge. He closely followed the Armenian press and the articles published in it. In the letter addressed to Kostan Zarian, he strongly criticizes the journalists of "Haraj" newspaper: "The press is in the hands of unprepared people. "Haraj" is a nest of vultures, uneducated and ignorant puppies, to talk to, to quarrel with them would mean to honor them, to humiliate one's own dignity.

At Arshak Chobanian's request, the armenologist's letter-opinion on Abgar Payazat's book The Key of the Khaldi Language was addressed to the latter. Adonts does not share the contents of Hrachia Ajarian's warm preface written in old Armenian at the beginning of the book. He sees mistakes, errors, self-explanatory interpretations in it. He compares some of the Payazat's linguistic inventions with the history of the Armenian peasants, according to whom the word minister was borrowed by Russians from Armenians. In Armenian minister means do not sit, because the minister has no right to sit before the king. "We should note with regret that the etymologies of Payazat are of such inventions.

Adonts' last letter is addressed to Artashes Chilinkarian. We learn from it that in 1939 the scientists went to Paris and gave a lecture on "Armenian national epics David of Sassun". Unfortunately, the speech about the Armenian national epics David of Sassun was oral, without a note. In order to make the lecture written he needed time that he did 
not have. World War II broke out in Europe, which deeply depressed the scientist, he hated revolutions and wars. In addition, he had serious health problems. And for the first time in one of his letters we see despair; "The turbulent atmosphere affected me so much that I felt the weakness that comes from old age or depression. There is no hint of a bright, cheerful light, neither personal, nor patriotic, nor anywhere, that would bring relief to my frozen essence with new hopes. I am afraid that my plans will be incomplete or as depressing as I am.

At the beginning of his emigration years, Adonts confessed that leaving his homeland, he left his relatives hopeless, in fact, preferring to serve the nation and science. He always dreamed of the rebirth of his homeland.

On April 24, 1929, during the commemoration of the victims of the Armenian Genocide in Paris on his own initiative and under his presidency, he addressed his compatriots with brief and influential words: "There is no victory without defeat. When branches of a tree are cut down, it sheds fresh branches. Each of you must fulfill his duty for the sake of freedom.

Adonts "Correspondence" contains numerous letters addressed to N. Marr, N. Akinian, G. Hovsepian, T. Gushakian, K. Zarian and others, the theses in which are basic and can still be used by linguists, critics, politicians, historians and people involved in science in general.

\section{Discussion}

The article presents for the first time N. Adonts' scientific, pedagogical and research interests, which are expressed in his letters. These letters are addressed to Armenian and foreign scholars, various representatives of of the periodicals, dedicated to Byzantines studies, armenology, pedagogy and other important issues in other fields. They were the life guides of the scientist and contributed to the general development of the scientific fields he chose.

\section{Conclusion}

The letters by L. Adonts have never been observed from the pedagogical point of view. This is the first attempt. He has passed through a long scientific and pedagogical way. The well-known professor has taught for long years in the University of SaintPetersburg. His fame was especially spread when in 1931 a Chair of Armenology was opened in the Brussels University especially for him. He remained its responsible until his death. In his letters of the first period Adonts is already presenting how important are scientific honesty, discipline, the profound knowledge of the chosen field and of different languages, as well as awareness of the international experience. 
His letters make it clear how many international scientific and pedagogical ties had the professor.

Adonts' letters are very important to study today for scientist who devoted themselves to pedagogy.

\section{References}

Adonts N. G. (2006). Works I, Historical Scientific Researches, Yerevan, Editions of the State University of Yerevan, 535-546.

Adonts N.G. (2012). Works VI, (additional volume), Public Speaking, Yerevan, Editions of the State University of Yerevan.203-205, 366.

Adonts N.G. (2014). Works VII, Correspondence, Yerevan, Editions of the State University of Yerevan, 37, 35, 39, 42-49, 58, 60, 89, 92, 93, 150, 176, 185.

Frik (1952). Collection of Poems, New York, Publication of the Armenian general Benevolent Union Melkonian Fund.

Mushegh Ishkhan (1952). Three Great Armenians, Beirut, Printing House "Etvan”, p.17. 